\title{
АСПЕКТЫ ИЗУЧЕНИЯ ВЕРБАЛЬНОГО УРОВНЯ СКОТОВОДЧЕСКИХ ОБРЯДОВ
}

\author{
Людмила Лобанова \\ sergejluda@mail.ru
}

\begin{abstract}
Аннотация: Статья посвящена анализу вербальной составляющей скотоводческих обрядов. Заговорно-заклинательные тексты по жанровой природе разделены на пять разновидностей: приговор, ритуальный диалог, заговор, причитание и молитва. Наибольшее распространение получили приговоры. В результате структурно-семантического анализа приговоров выделены два типа текстов. Приговоры закрытой структуры состоят из двух частей, которые могут быть в отношениях противопоставления и сравнения. Приговоры открытой структуры разделены по адресатам: животным, святым, домовому.
\end{abstract}

Ключевые слова: скотоводческая традиция коми, заговоры, приговоры, причитание

\section{Скотоводческая традиция коми}

В традиционном хозяйстве коми промысловые отрасли (охота и рыболовство) дополнялись скотоводством и земледелием, при этом первое являлось необходимым условием для развития второго: скот держали в основном для получения навоза, без которого скудные земли были непригодными для выращивания 
сельскохозяйственных культур. В условиях крайнего севера, где стойловый период составляет 7-8 месяцев, животноводство являлось трудоёмким процессом, к тому же ограниченным площадью сенокосных угодий и пастбищ. Традиционно было распространено разведение крупного рогатого скота - в целях получения молочной продукции для личного потребления, лошадей - в качестве тягловой силы и транспортного средства, овец - для получения шерсти. Для содержания скота были предусмотрены специальные помещения (гид, гидня, шы, кар$m a)$, интегрированные в жилой комплекс: тёплое - для коров, и холодное - для овец и лошадей. Скот на подножном корму находился 4-5 месяцев и пасся без присмотра, в ряде традиций практиковалась отправка скота на летние пастбища. До 1930ых гг. поголовье скота в личных хозяйствах в зависимости от величины семьи и владения сенокосными угодьями составляло: коров 1-10, лошадей $1-3$, овец $3-15$. С введением коллективной собственности поголовье скота на личных подворьях стало уменьшаться. Рост поголовья крупного рогатого скота отмечался в 1990-ые гг., а в последнее десятилетие наблюдается резкий спад, что связано с әкономической ситуацией и состоянием сельского хозяйства в целом по стране.

В области духовной культуры животноводство представлено комплексом ритуалов, верований, поверий, примет, предписаний, запретов, магических приёмов, заговорно-заклинательных текстов и т. д. и в целом является ритуализированной деятельностью. Все действия по уходу за скотом, даже самые утилитарные, повседневные, могут приобретать магическое осмысление.

Скотоводство как область традиционных занятий требует освоения не только практических навыков по уходу за скотом, но и овладения определёнными знаниями, называемыми в народе скӧт гӧгӧр тӧдӧм 'знание по скоту (букв. вокруг скота)'. Освоение этих знаний происходит со сменой социального статуса, когда девушка выходит замуж, заводит семью и хозяйство, становится хозяйкой. Чаще всего под «знаниями вокруг скота» (иногда конкретизируется, например, мӧс гӧгӧр тӧднь 'знать вокруг коровы') понимается владение охранительной, продуцирующей и лечебной магией, включая выполнение обрядовых действий и отправление заговорно-заклинательных текстов ${ }^{1}$ : 
Пӧрысьясьц ёна скӧттӧ видзлісны и меныли тоже передайтэлась, и ме скӧтӧн же ола. Зэв унатор висьтавліснь, кор ме ичӧт на вӧлі, изэв унатор кывлі. Миян ььджыд мамыс вӧлі шуӧ, ӧти женщина миян татӧн вӧлӧмалӧс тӧдьцсь, сёр пос волӧныс стадаьıс ставнас миянладорысь вӧлі мунӧ неляльн кылиьн лӧс, и если кӧ пе ме ӧні кӧсъя, шува пе кутшелке кыв, и став мӧскыс пе татчи пласьт усяс, мььйла пӧ лӧс гӧгӧрыс нинӧл оз тӧдны, некутшем молитва пӧ мӧскысльь абу льљделаэсь. Ме пӧ ӧні пӧрысь нин, да сійес ог нин вӧч. И вот, значит, ми, ӧнія йӧз, молитваяссэ мӧс гӧгӧрыс нинӧм ог тӧдӧй, сы вӧсна вермасны тӧдысь да кужысь йӧз мӧстӧ весиг висьлӧдны. ${ }^{2}$
Пожилые много скота держали, и мне тоже передали, и я со скотом живу. Многое говорили, когда я ещё маленькая была, и многое слышала. Моя бабушка рассказывала, что была здесь одна женщина - знающая коров. И однажды, когда через мост переходило стадо коров, около сорока голов, она сказала, что если захочет, то скажет какое-то слово, и все коровы тут же пластом лягут, потому что [хозяева] ничего не знают вокруг коров, никакую молитву не прочитали. Но я, говорит, сейчас стара уже и не пойду на такое дело. Это означает, что мы, нынешние люди, не знаем молитв вокруг скота, и поэтому знающие и умеющие люди могут напустить болезнь на скот.

Отсутствие таких знаний, неординарный или более серьёзный случай приводит к необходимости обращения к помощи знающих-тӧдысь, знание которых, среди прочего, определяется обладанием заговорных слов - нилкыв ${ }^{3}$, что также отражается в наименовании этих людей - нилкььв видзысь, ныллкывъя, нилкыв кутысь,- которым приписывается способность как лечить животных, так и наводить порчу. 
(Висьтавліснь, мльй Саввӧьс тиькӧдлӧла мортӧс ли скӧтӧс?) Но так сія пӧ ёна тшыкӧдчылӧла. Сія ачьıс пӧ ошйьıсьӧм. Me пӧасылнас пӧчечча, кыльчӧ вылӧ пе пета, нилкьлсӧ пӧ лэдза, и тӧлнас пӧ кьччи нуё (а сэн Кось саяс яг, Вайлиӧс яг, сэн Вайлиӧс-ю, но и Вайлӧс ягӧн шуӧны, сэсся пӧмеял нилкьлйьс), тӧлнас нилкылсё тӧлзьӧдӧ, кутшӥм пуӧ веськалӧ, сія пуыс косьлӥ. Сія пӧ ошйьıсьӧ, Косьватас пӧ Лихачевка ватасыс, став пӧ меяли понысь кос пессӧ сотӧ, кос кондасӧ, ciя пӧ пуыьс косьлӧ, сія сэсся пес вылӧ ваялӧны, менам понысь пӧ ставыс Лихачевка ватасыс пессӧ comӧны. ${ }^{4}$
(Рассказывали, что Савва наводил порчу на человека или скот?) Так он, говорят, на многих навёл порчу. Он сам, мол, хвастался. Я, мол, утром встану, выйду на крыльцо, заговор-нимкыв пущу, и ветром, мол, куда унесёт (там за деревней Кось <Лихачевка> есть бор, бор Ваймӧс, там река Ваймӧс, но и бор Ваймӧс называют), ветром заговорнимкыв уносит, в какое дерево попадёт, то дерево и высыхает. Он хвастается, мол, всё население в окрестностях Лихачевки, все от меня сухие дрова жгут, сухостой, мол, деревья высыхают, и их потом на дрова привозят, моими дровами всё население в окрестностях Лихачевки топится.

\section{Характеристика источников}

Наше исследование основано главным образом на экспедиционных материалах, записанных в форме интервью с носителями традиции на различные темы, связанные со скотоводческой традицией (содержание и уход за скотом). В содержательном плане записи представляют собой не наблюдения за реальными обрядами (фиксация ритуальной практики в момент исполнения), а устные описания обычаев (что обычно делают, когда выпускают скот на пастбище), конкретные случаи из жизни (как 
вылечили опухшее вымя коровы или как заводили купленную корову в хлев), воспоминания, рассказы, поучения и т. д. ${ }^{5}$ Безусловно, идеальным вариантом было бы наблюдение за обрядом и его фиксация в момент реального осуществления, но в условиях фольклорно-этнографических экспедиций исследователю нечасто удаётся фиксировать реальную ритуальную практику.

Такого рода материалы были выявлены также в архивных рукописях ${ }^{6}$, в опубликованных лингвистических и фольклорных материалах (см. Syrjänische Texte 2006, Zyrian Folklore Texts 1978) и исследованиях, посвящённых изучению магических представлений и заговорно-заклинательных текстов (см. Ветошкина 1982, Кудряшова 1991, Сидоров 1997). Кроме того, значительная часть материалов представлена заговорно-заклинательными текстами, выбранными из рукописных тетрадей инорормантов ${ }^{7}$.

При подобной фиксации материала невозможно дифференцировать скотоводческие обряды по принципу наличия или отсутствия вербального уровня, изучить вариативность текстов. В то же время данный формат позволяет проанализировать контекст бытования заговорно-заклинательных текстов и народные представления о роли слова.

\section{Проблема выделения вербального компонента}

Большинство материалов записано в форме интервью, в котором информант рассказывает об обряде, описывает действия и события, в то время как вербальный компонент уходит на второй план. Этому способствует сам тип подобного речевого высказывания, а также вопросы собирателя: что делали, когда корова не давала молока; как выгоняли скот первый раз на пастбище. Поэтому о вербальной составляющей ритуала часто приходится спрашивать дополнительно.

( Кьдзи мӧстӧ лудад медводдзаысь лэдзан?) Сійес вот лӥстэ ләдзан,
(Как выпускаешь корову первый раз на луг?) Эту вот корову выпускаешь, весной 
например, тульснас лэдзан первой после зиль, значит, миян сійе тоже, ог тӧд, коді висьталіс бабйес ли, сиктсаясьь ли, тоже менал прилета. Кор лиӧкьц петэ, бӧрья коктуйяссэ ме гидйас бӧр шььбита, лед тӧднь горт мӧдас. Сійа муас коле коктуйьс, и сійе мусэ, мед и куйедас шагнитас, куйедсэ сійес гидйас бӧр шьбита. (Мьй шувад?) Кьљзи коктуйьц сэн олэ, сідз же мед вӧлі локтэла татче. Ас кьвйеснад, вед дзик же сідз, ас кььвйесэн составитэла. ${ }^{8}$

Вербасӧ ваян, а Ёгорей луннас нин сійӧс [скӧтсӧ] лэдзӧны видз вылӧ, и сійӧн сійӧс швачӧдӧны вербанас. (Мыцикӧ шуалӧньц?) а «ёгорбатюшко, скӧтӧс видзхранитл-тадзи, аме сэсся ог möд. ${ }^{9}$ выпускаешь первый раз после зимы, значит, у нас это, не знаю, кто мне говорил: бабушки или односельчане, тоже есть примета. Когда корова выходит из хлева, последний след я бросаю обратно в хлев, чтобы дом знала. Так след остаётся на земле, и эту землю, пусть и в навоз шагнёт, навоз этот обратно в хлев бросаю. (Что говорите?) Как твой след там хранится, чтобы ты также возвращалась сюда. Своими словами, ведь точно также своими словами составлено.

Вер бу прин есёшь, а в Егорьев день его $<$ скот> уже выпускают на пастбище, и его хлестают этой вербой. (Что-нибудь говорят?) А «Егорийбатюшка, храни-береги скот» - так, а больше я не знаю.

В большинстве случаев заговорно-заклинательный текст органично вписан в рассказ информанта и описывается наряду с действиями. Он вводится при помощи глагола говорения в форме прямой или косвенной речи, указывая при этом на одновременность действия и слова, реже на их последовательность. Например: 
Ветль лися кладбищеӧ, боссь кладбишесьыс щепка, пу щепка. Локтан да мыйкӧ гид белляс вӧч розь, да щепкасӧ сэтчӧ, шуан: "Кьљз тая щепкасӧ тувьялі да оз вӧрзьь, сідзжё мӧскысльсь меял мед нелтор оз ворзьӧд» ${ }^{10}$

(А мӧскыдлӧн кутшӥм праздникыс?) Ог тӧд. A вӧо тай, шуаснь, тувсов Ёгорей лун, шестое маянад. Cійе пе вӧвлӧн праздник, вӧвбясэс йиреднь лэдзласны. Тошнад пе, Егорей-батюшко, йиред вӧӧястэ. Егорейьс ли мьий ли йиредэ ли мыєй ли. Сідз тай вӧлі шуласньь. (Вӧвтэ ләдзиген шувасньь?) Да. ${ }^{11}$
Сходи, мол, на кладбище, возьми щепку, деревянную щепку. В е рнёшьс я, в дверном косяке хлева сделай дырку, щепку туда [забей], скажи: «Как эту щепку забила, и не тронется, пусть и с моей коровы ничего не тронется».

(А у коров какой праздник?) Не знаю. А у лошадей так, говорили, весенний Егорьев день, шестого мая. Это, мол, праздник лошадей, лошадей выпускали пастись. Бородой, мол, Егорий-батюшка, накорми лошадей. Егорий иль кто, накормит иль что. Так вот говорили. (Выпуская лошадей говорили?) Да.

Кроме того, многие глаголы передают способы произношения вербального текста: льљдыьцы 'прочитать, перечитать, перечислить', горӧдчыныь, горзыныь, горзыштавны 'выкрикивать, перекрикиваться', шӧпкӧднь '(про)шептать'. Например:

«Гортӧлоктӧ, тайтӧ, лок, тайтӧ-тайтӧ. Лёкбясльь эн сетчё, некодль эн сетчьь. Кӧиндяс, лёк йӧз мед тәд оз мешайтны. Места тӧд, леста тӧд!" Тадзи горзісны Ыджыд Четвергад пач трубаад. ${ }^{12}$
«Идите домой, коровушки, домой-домой! Плохим не поддавайтесь, никому не поддавайтесь. Волки, злые люди пусть тебе не мешают. Место знай, место знай!» Так выкрикивали в печную трубу на Великий четверг. 
В рассказах исполнителей встречаются также различные номинативные названия, такие как кььвяс, нилкыв, примета, загӧвӧр, лолитва, употребляемые как синонимы для обозначения заговорно-заклинательного текста. Кроме того, заговорнозаклинательные тесты могут именоваться по объекту воздействия, например висьӧмысь 'от болезни', тшькӧдӧльсь 'от порчи', волидзысь 'от сглаза', на устранение или избавление от которого направлен текст. Интересны в данном случае названия, такие как скӧтысь 'от скота', мӧскысь 'от коровы', мӧс локтӧмысь 'от возвращения коровы', которые возникают по вышеприведённым аналогиям, на основе готовой языковой формы, и информатор не задумывается об их значении: «Святые священнолученики, Власия, молите бога о нас». Тайӧ скӧтысь молитва. Скӧтыд мыйке лоэ, да тайе молитчены. ${ }^{13}$ 'Это от скота молитва, со скотом случится что-либо, и молятся так'.

Нередки наименования заговорно-заклинательных текстов по имени христианского святого, являющегося адресатом текста, а также по первому слову или основному мотиву текста, что в первую очередь способствует сохранению текста в памяти исполнителя. Например:

(Кор первойысь скӧттӧ лудӧ лэдзан, мыцй вӧчан?) Но кутшёмкӧ молитва

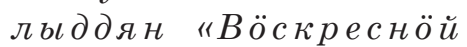
молитван, сәсся ёгорей, шестое, сән кутшӧлкӧ молитва выйьлм да, выйыıл, выцйылм, дул вылӧ оз усь, сразу дул вылӧ оз усь. Егорейыслӧн на выйылм кутшӧлкӧ молитва <...> «Христос с тобой Егорий храбрый, прили мою животину на всё полное лето и спаси ux!»14
(Когда первый раз выпускают скот на пастбище, что делают?) Тогда прочитаешь какую-либо молитву - «Воскресную молитву» ${ }^{15}$, потом Егорий, шестого, там какая-то молитва есть, молитва есть, есть, но сразу на ум не приходит. Ещё у Егория есть какая-то молитва: (далее по тексту оригинала) 
Сэки кресталэны ӧдзестэ, водзджык идрасясны, и кресталэны вӧлэл зӧлӧтэй толанэн пе. "Кристос печать, йигно-толно зӧлӧтӧй толаннад, зӧлӧтэй ключнад» Карта ӧдзестэ тадзи кресталэны да шувалэны.. ${ }^{16}$
Тогда перекрещивают д в е ри, пор аньш е справляются со скотом, и перекрещивают «золотым замком", мол. "Печать Христа, закрой-замкни золотым замком, золотым ключом» Двери хлева таким образом перекрещивают и проговаривают.

\section{Жанровые разновидности}

Заговорно-заклинательные тексты, функционирующие в составе скотоводческих обрядов, можно разделить на пять разновидностей: приговор, ритуальный диалог, заговор, причитание и молитва. В последнем случае имеются в виду канонические молитвы, произносимые в составе скотоводческих обрядов. Подробнее остановимся на них ниже ${ }^{17}$.

Основная проблема заключается в разграничении приговоров и заговоров, в силу того что одни и те же тексты в некоторых исследованиях называются приговорами, в других - заговорами. В российской фольклористке сложилась следующая тенденция. Когда заговор употребляется в значении «заговорно-заклинательный текст» и обозначает словесный способ магического воздействия, приговоры не выделяются. При разграничении заговоров и приговоров основываются на ряде признаков, характеризующих их как противоположности: объёмные тексты со сложной структурой и выстроенной композицией - краткие словесные формулы; преобладают над действием - вторичны, производимы, зависят от действия; принадлежат к профессиональной среде, тайному знанию, сакральным лицам - общеизвестные, бытовые знания; часть специально проводимого ритуала - сопровождают практические и обрядовые действия. Но при обращении к конкретному фольклорному материалу категоричность размывается, выявляются переходные формы, и исследователи склоняются к использованию обобщённого термина - заговоры (Федосова 2007). В настоящей работе приговоры 
и заговоры рассматриваются не как противоположности, а как разные формы и способы словесно-магического воздействия, которые могут быть выделены по материалам скотоводческой традиции коми. Однако, сразу следует оговориться, что указанный ряд жанровых разновидностей не исчерпывает все возможные варианты, поскольку встречаются тексты с неопределённой жанровой спецификой (когда текст вырван из ритуального контекста), а также переходные и контаминационные формы.

\section{Приговоры}

Бо́льшую часть зафиксированных текстов мы определяем как приговоры - краткие вербальные формулы, которые сопровождают различные практические меры по уходу и содержанию скота (стрижку овец, дойку коровы, выгон скота на пастбище и др.), сообщая утилитарной практике ритуально-магическую функцию, либо являются частью специально проводимого ритуала, имеющего продуцирующую или апотропеическую функцию (на здоровье коров стегают вербными ветками; от порчи перекрещивают молоко и др.).

В первую очередь, выделяются приговоры, выраженные междометиям. Они относятся к разряду императивных междометий (волеизъявления) и используются для призыва животного к осуществлению или прекращению какого-либо действия. В некоторых случаях в отдельную группу выделяются вокативные междометия, которыми подзывают или отгоняют животных (Попова 2000: 522).

Тӧлӧ (диал. тӧлэ) (ССКЗД 1961: 375) - окрик корове во время дойки, выражающий требование прекратить какое-либо движение и стоять спокойно. Этимология выражения не выявлена, возможно, от ӧлӧдны 'остановить, унять'.

Тайтӧ (диал. тайтэ, татьӧ) - зов коровы, обращение к корове (ССКЗД 1961: 363), в основном используется для призыва коров вернуться домой с выпаса, хозяйки приговаривают, загоняя корову в хлев. Этимология неясна, возможна связь с наречиями, местоимениями и частицами с усилительно-выделительной и указательной семантикой: тайӧ 'этот', татчӧ 'сюда', тай 'вот здесь'18. 
Вала-вала-возглас, которым подзывают коров на водопой (Жилина 1975: 161).

Tnpy - возглас, которым останавливают лошадь, управляя ею, или выкрикивают, добиваясь усмирения и успокоения, подходя к ней или проводя осмотр.

Öсьт-ӧсьт (диал. тӧсь-тӧсь, ӧсьтӧ-ӧсьтӧ, ӧсьта-ӧсьта) возглас, которым кличут овец (ССКЗД 1961: 267). Этимология неясна, в современной речи в подобных случаях чаще используется баль-баль, производное от бале 'ягнёнок'.

Телят, бычков подзывают возгласами тnрутьӧ-тпрутьӧ (диал. тпрути-тпрути, тпруте-тпруте, пруть-пруть) и конь-конь (диал. коне-коне). В последнем варианте, по предположению лингвистов, сохраняется общепермская основа *kon' 'телёнок' (Лыткин \& Гуляев 1999: 133). Жеребят подзывают возгласом чиб-чиб (диал. чибӧ-чибӧ, чибе-чибе) (ССКЗД 1961: 410), являющимся производным от слова чибӧ 'жеребёнок'. Некоторые из рассмотренных междометий встречаются в качестве обращений в заговорно-заклинательных текстах и будут рассмотрены ниже.

В основном приговоры равны одному высказыванию, построены по модели директив, с использованием императивных форм глаголов. На основе современных материалов, обзор которых приведён выше, мы не можем выделить конкретного народного наименования этих выражений. В более ранних записях подобного рода словесно-ритуальные действия называются вордчыны :

Сәсся вӧлі ыж шыриген в ордчен нь. ЫҢ бе с шырасны да вурунсэ босьтасны киас да шуалэны, зыралэны мыци вывсэ и быцэн да шуэны:

Кӧчен лун,

Сюзен лок.

Кӧин кулаль ин шедэдчы, Потшыс коласэ юртэ ин сюй, Ассььљд кӧзяин-кӧзяйкатэ möd, Гортэ волььльь. ${ }^{19}$
Потом ещё во время стрижки овец предрекали. Овцу постригут, шерсть возьмут в руку и проговаривают, трут по спине и целиком и говорят:

Зайцем уходи, Совой возвращайся. Волку-куме не попадись, Меж жердей голову не суй, Своих хозяина-хозяйку знай, Домой возвращайся. 
Глагол вордны в коми языке встречается как диалектный вариант глаголов синь 'желать, пожелать, предопределить' и тунавны 'предсказывать, пророчить, предвещать' (ССКЗД: 60, 337,381 ), а также может употребляться в значении 'заклинать, загадывать'. В отличие от диалектных вариантов, этимологически глагол восходит к слову вор 'дар речи' (КЭСК: 63), поэтому вордчыны может быть переведено как 'предрекать'. Несмотря на то, что указанная функция не эксплицируется в современных записях, она сохраняется за подобными словесно-магическими актами. Их цель - проговаривание желаемого хода события, ожидаемого результата. Эти тексты произносятся с определёнными действиями практического или магического характера, поэтому мы определяем их как приговоры.

Несмотря на разнообразие приговоров, возможно выделение двух структурных типов. В основе приговоров закрытой структуры $\iota^{20}$ (залкнутые фбразовые изречения - по Григорию Пермякову (1988: 95); заговорно-заклинательные фборлуль по Валентине Харитоновой (1992: 3-37)) лежат клише из двух частей, которые могут быть в отношениях:

- противопоставления: «Зайцем уходи, совой возвращайся», где противопоставлены предикаты (уходи - возвращайся) и объекты (заяц - сова), причём заяц и сова - по признаку шерстистости ${ }^{21}$ : у зайца шерсть короткая и тонкая, а у совы - длинная и густая. Также, например, приговор Бӧр туйсэ вунэд, водз туйсэ вӧт 22 'Обратную дорогу забудь, наперёд дорогу представь', произносимый при вводе купленной коровы в хлев. Эти выражения отличаются метафоричностью. - сравнения, когда первая часть текста (как..., где...) описывает исходную обрядовую ситуацию и актуализирует нужный признак, а во второй части моделируется желаемая ситуация: Кыљз тая щепкасӧ тувиялі да оз вӧрзьы, сідзжӧ мӧскысльсь меял мед нелтор оз ворзьӧд. ${ }^{20}$ 'Как эту щепку забила и не тронется, так же пусть и с моей коровы ничего не тронется; Кьљзи тая саис лэбзяс да ылла воше, мед менам вӧл вылісь тадзи же лэбзяс волидзис! 'Как эта сажа разлетится и исчезнет на улице, пусть с моей лошади также улетит сглаз' (Uotila 2006: 312). 
Матёнка Туся, кӧн тэнад бурсиыд да бӧжьд, сэтӧн мед тэнад войсӧ телӧьљ. ${ }^{21}$ 'Матёнка Туся (букв 'Ягодка'), где твои грива и хвост, там пусть ночью твоё тело [будет]'

К этой же группе мы отнесли приговоры, составленные в форме ритуальных мотивировок:

Трӧича рос тоже вӧлэл пыртэны керкаэ ен доре, лӧсъястэ на вачкылэны, мед пе трӧича рос кодь здоровеесь лоанныц. ${ }^{25}$

Мед берба-баля кодь здоровейесь мед, зӧлӧтаяс, лованныц. ${ }^{26}$
Троицкие ветки также заносили домой к иконам, коров ещё хлестали: чтобы были здоровыми, как троицкие ветки.

Чтобы вы словно барашки вербы здоровые, золотки, были.

Иной тип представляют приговоры открытой структуры (незалкнутые фбразовые изречения - по Г. Пермякову). Подобного типа приговоры можно сгруппировать по адресатам. Адресатом первой группы приговоров выступает животное. Ниже приведены примеры приговоров из разных источников, исполняемые при стрижке овец, в которых продемонстрирован открытый характер подобных текстов - от короткой паремии до выражений, содержащих обращение и перечисления:

Ыжль тотшкӧны юрас шььригас: "Шыран кад möd». ${ }^{27}$

Кӧзяйкаяс, кор шырӧньь ью, то сэк шуалӧны: «Öсbт-ӧсьт / шыран кад тӧд / кӧйинльь эн сетчьь / кӧрт потшӧс волӧн звирк четчьщт / гоз баля вай». ${ }^{28}$
Овцу стукают по голове при стрижке: «Знай время стрижки».

Хозяйки, когда стригут овец, тогда говорят: «Овечка-овечка / знай время стрижки / волку не поддайся / через железный забор перепрыгни / пару ягнят принеси». 
Ыж шыриген: «Ӧсьт-ӧсьт / шыран-кад тӧд / Ёмабабалі эн сеччи / бӧр гортэ лок / эн сечи!! 29

(Шыригас нинэл оз вӧлі шуавные?) А вед нинэл, шыригас только шыран воропен колскебта, Агниес тшӧкта же "Шыран кад тӧд / кӧрт потшысәд чеччыщт / лёк Ёлаль эн сетчи». ${ }^{30}$

Шырны заводитігас юрас таркедэны шыраннас. «Пась кодь яя / сюрия кодь нэла / кӧртэн-пуртэн вийтэг / эн кув». ${ }^{31}$
Обстригая овцу: «Овечкаовечка/ знай время стрижки / Бабе-Яге не поддайся / обратно домой возвращайся / не поддайся».

(Во время стрижки ничего не приговаривали?) Ничего, постригая только ручкой ножниц стукаю, Агнию <дочь> тоже заставляю: «Знай время стрижки / через железный забор перепрыгни / злой Яге не поддайся».

В начале с триж и стукают <овцу> по голове ножницами. "Как шуба мясистой / как столб долговечной / не зарезав железом-ножом / не умри».

Приведённые приговоры, произносимые во время стрижки овец, сообщают модель поведения животного, на основе которого можно выделить практическое назначение ритуала - обеспечить сохранность животного до следующего периода стрижки («знай время стрижки», «перепрыгни через железный забор / изгородь в семь прясел», «не поддайся Ёма-бабе» ${ }^{32}$, «не удавись на жерди», «не попадись собаке», «будь долговечной, как столб», «не зарезав железом-ножом, не умри»), улучшить его функциональные характеристики, в частности, шерстистость («знай время стрижки», «зайди в кум с шерстью, и принеси хозяйке хорошую шерсть») и плодовитость («пару ягнят принеси»).

Особенностью приговоров, адресованных животным, выступает совпадение адресата и реципиента. И как можно заметить, в большинстве случаев адресат и реципиент пропущены на вербальном уровне, но они акцентируются действием, которое 
предваряет либо сопровождает текст, в рассмотренных примеpax овцу стукают по лбу ножницами. И только в двух текстах содержится возглас ӧсьт-ӧсьт, которым окликают овец. В то же время в приговорах, сопровождающих ритуальные действия по отношению к корове, всегда маркирована кличка, масть животного с приложениями матушка, матёнка, рабича божья, в чём выражается почтительное отношение к корове и её статус в хозяйстве, с одной стороны, и ритуальная речь - с другой: Бласлӧ Кристос, Лунашка-матушка, давай эн сетчь скӧтльь, этӧ лёк

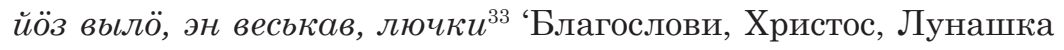
(букв. 'Денька') матушка, не поддайся зверю, не попадись плохим людям, хорошо [чтоб всё было]'.

Адресатом других приговоров являются христианские святые Егорий, Власий, Харлампий, Модест, Анастасия, Флор и Лавр, которые в народных представлениях выступают покровителями и охранителями скота и скотоводства, иногда именуются как «скотьи боги», а памятные даты святых именуются вӧв праздник 'праздник лошадей', вӧв ниллун 'именины лошадей', лӧсль молебен лун 'день молебна коров' и т. д. Подобного типа приговоры могут содержать следующие элементы: обращение, ядерную формулу, реципиента и перечисления.

Ёгор-батюшко, скӧтӧс видз-хранит ${ }^{34}$ 'Егорий-батюшка, сбереги-сохрани мой скот'

Святы Ласей, святы Настасья, святы Модес, святы Харлампия! Видзей да бережитэй менсььлм Милка-латушкаэс

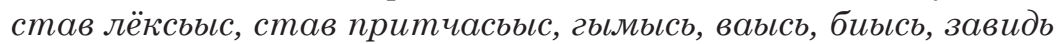
синдясысь. ${ }^{35}$ 'Святой Власий, святая Анастасия, святой Модест, святая Харлампия! Берегите и сохраните мою Милку-матушку от всего плохого, всякого несчастья, грома, воды, огня, завидных глаз'.

Господи благослови, святый Уласей! Сохрани и бережи от всяких хишных зверей и от зльх людей. ${ }^{36}$

Визюк ли Серед матушкаль, Господе, сет здоровье, избавит лёк йӧзысь, лёкьсь-притчась, ьљджыд милӧстьнад ${ }^{37}$ 'Визюк или Серед (букв. 'Пёстрая, Чёрно-белая') матушке, Господи, дай здоровья, избави от плохих людей, худа-несчастья, большой милостью'. 
Адресатом третьей группы приговоров является мифологический персонаж - домовой. По народным представлениям, он обеспечивает благополучие и плодовитость обитателей хлева, а также может негативно повлиять на скот при нарушении норм и правил. Обычно приговоры домовому произносятся в обрядах:

- перехода в новый хлев: Дӧлӧвӧйӧ-двӧрӧлейӧ, батюшкаӧматушкаӧ, корлиличай-маменькаӧ, кудз ассьыныд дитяясныдтӧ любитаныд да жалейтаныд, сідз жӧ и мисьыныли пар скӧтинанылиӧ любитӧ и жалейтӧ, пӧитӧ и кӧрлитӧ. ${ }^{38}$ 'Доловой-дворолей, батюшка-матушка, кормилица-маленька, как своих дитяток любите и жалеете, так же и нашу скотину любите и жалейте, поите и корsume.

- ввода новокупленного или новорождённого животного: Дедушко-батюшко, дедушко-матушко! Я тебе гостинииь принёс. Мою скотину корли, пои да на масо глади, да приголубь и шерсть очищай. ${ }^{39}$

Следует отметить, что приговоры с обращениями к домовому зафиксированы в прилузской и удорской традициях коми, которые характеризуются тесными контактами с русским населением Кировской и Архангельской областей.

От обыденной речи, речевых высказываний тексты приговоров отличает ритуальность ситуации и наличие в текстах рифомы, ритма, повторов (Славнӧй Ёгорей, благӧславнӧй Ёгорей, сохрани-бережи 'славный Егорий, благославный Егорий, сохрани-сбереги'), перечислений (любитӧ и жалейтӧ, пӧитӧ и кӧрлитӧ 'любите и жалейте, поите и кормите'), деминутивов (дедушко-батюшко, корлиличаӧ-лаленькаӧ 'дедушка-батюшка, кормилица-маменька') и отмеченная выше метафоричность.

\section{Заговоры}

Заговоры имеют сложную структуру и композицию, состоят из нескольких высказываний, произносятся в специально проводимой обрядовой ситуации. Семантика большинства заговоров может быть определена как реабилитирующая, они направлены 
на исправление и восстановление нормального состояния домашних животных и выполняются, «чтобы вылечить заболевшее животное», «чтобы ночующая на стороне корова возвращалась домой» и т. п.

Тексты заговоров зафиксированы нами в контактных зонах, представляют удорскую и прилузскую традиции, в языковом плане и по образному строению близки к северно-русской традиции. В основном эти тексты содержатся в рукописных тетрадях информантов наряду с частушками, песнями, каноническими молитвами, что в целом характеризует эти записи как записки на память, чтобы не забыть. Некоторые информанты указывали, что записывали тексты со слов матери или другой женщины, отличающейся хорошим знанием "вокруг скота». Кроме того, в записанном виде тексты могли передавать сами носители этого знания. В случае необходимости текст заговора перечитывали, восстанавливали по памяти или заучивали. Остановимся на некоторых примерах.

Мӧс локтӧльцсь.

Во иля отиа - 3 раза

На правой руке каленнӧй стена

На левой руке железного стьнна

на переде высокӧй гӧра раба божия Серук мӧс

моз вермы мунны

чужӧй пӧскӧтинаӧ.

чужӧй картаӧ ${ }^{40}$

чужӧй кӧзяйкалӧн ${ }^{41}$

Старӧй кӧзяйкалӧн сёянюаныс

твёрдӧй калень да льсс.

Выль кӧзяйкалӧн сёянюаныс

свежӧй трава да мягкӧй хлеб. ${ }^{42}$
На возвращение коровы (букв. 'от возвращения коровы'). Во имя отца - 3 раза На правой руке каменная стена,

На левой руке железный стын, Впереди высокая гора. Раба божия Серуккоровушка, Чтоб не смогла уйти На чужую поскотину, В чужой двор.

$\mathrm{У}$ чужой хозяйки У старой хозяйки еда-питьё Твердый камень и хвоя. $\mathrm{У}$ новой хозяйки еда-питьё Свежая трава и мягкий хлеб. 
В тексте можно выделить следующие структурные части:

- экспозиция, которая зафиксирована не полностью и может быть восстановлена как «Во имя отца и сына и святого духа», читается три раза;

- повествовательная часть: На правой руке каменнӧй стена / на левой руке железного стьна / на переде высокӧй гӧра;

- заклинательная часть раба божия Серук мӧс / моз верль мунны / чужӧй пӧскӧтинаӧ / чужӧй картаӧ. / Чужӧй кӧзяйкалӧн / Старӧй кӧзяйкалӧн сёян-юаныс / твёрдӧй калень да льс / Выль кӧзяйкалӧн сёян-юаныс / свежӧй трава да мягкӧй хлеб.

Судя по надписям в тексте между строк и комментариям информанта, данным во время интервью с ним, заговор использовался как при покупке коровы, так и при выгоне коров на пастбище.

Следующий текст в записях этого же информанта относится к тем случаям, когда заговоры фоксируются с целью передачи другому лицу. Надо отметить, что текст, в отличие от других записей в тетради исполнителя, написан чужим почерком и на отдельном пожелтевшем листочке. Комментируя записи, информант отметила, что заговор читается при любых несчастьях со скотом $^{43}$, а текст ей записала и передала старая бабушка из дер. Крестово ${ }^{44}$ :

Господи Боже свят Уласей, пололился и поклонился! И стань ко мне, рабыче божие (имя) Музе скӧтине и животине, телёне и балке. Святы и боже тоже постав бога вокруг дола реки огненье, стень каленье, стены железные от 200 киланет. От зелли и до небес, вовеки веков. алин. ${ }^{45}$

\section{Ритуальный диалог}

Вербальный уровень части обрядов представлен диалогом двух участников ритуала, состоящим из двух-трёх компонентов. Изучение ритуала-диалога в славянской традиции предпринято в работах Никиты Толстого (1984, 1993). Ритуалы-диалоги классифицированы и распределены по 11 тематическим рубри- 
кам. Одна из групп объединяет диалоги-ритуалы с магической фонкцией «удерживание птицы и скота дома». Основная цель ритуалов этой группы - привязать скот и птицу в предстоящий выпасной период к дому. В большинстве славянских традиций подобные ритуалы приурочивались к рождественской обрядности, а в северно-русской - к Великому четвергу или имели окказиональную природу (Толстой 1984: 26-30, Толстой 1993 : 85-87).

Подобные ритуалы зафиксированы в южных районах Республики Коми. Обряды проводились утром Великого четверга ${ }^{46}$ с целью приобщения скота к дому. Один из участников выходил во двор / на поветь или обводил корову вокруг дома ${ }^{47}$, а второй оставался дома, и между ними происходил диалог: Коровь-то дома? - Дола! Дола! - Овиь-то пришли? - Пришли! ${ }^{48}$ Считалось, что после этого коровы всегда будут приходить домой с выпаса. С некоторыми изменениями подобные обряды совершались в совхозном коровнике. Так, утром Великого четверга, придя на скотный двор, между доярками происходил диалог: Мӧсъяс ставыс абу? - Ставысставыс! '49 'Коровы все ли? - Все-все!', «чтобы коровы сами приходили с выпаса, не терялись».

Другие зафиксированные ритуалы-диалоги направлены на лечение и изгнание болезней у людей и скота. Н. И. Толстой, рассматривая эту группу, отмечает «заговорный» характер и распространённость этих обрядов среди русских, а также разнообразие способов изгнания болезней, которую окуривают, сжигают, рубят, выпаривают и т. д. (Толстой 1984: 45-50, Толстой 1993: 92-98).

В коми традиции зафиксированы ритуалы-диалоги при окуривании коровы. В некоторых случаях обряд проводится на третий день после отёла коровы. «Хозяйка брала миску, клала туда веточку можжевельника, несколько волосинок с головы, мох из трёх углов избы, щепку из порога дома, часть соломенной подстилки из своей обуви, кусочек ладана. Затем в хлеву сжигала всё это, образовавшийся дым давала понюхать корове и телёнку, а потом три раза обходила вокруг них. При этом происходил диалог с подставным лицом: 
- Мыıй тшынан,

Мыцй тшынан?

- Волидзкыь тшынна.

Тьббу волидз курваэс

Ёна колэ тшьнны.
- Что окуриваешь, Что окуриваешь?

- Заклинание окуриваю.

Тьфу, курву-заклинание

Сильнее надо окуривать».

Исследователь определяет цель проведения ритуала как «профилактика домашнего животного с помошью дыма от возможной порчи» (Ветошкина 1982: 89-90).

В других вариантах обряд окуривания проводится с целью избавления от болезни, возникшей в результате нанесения порчи на животное. В число предметов, которыми окуривается животное, могут входить можжевельник, принесённый на Великий четверг и хранимый в хлеву в качестве оберега, щучьи зубы, стружки от порога хлева, паутина, собранная в углах хлева, шерсть окуриваемого животного, отстриженная с крестца, лба и хвоста, остатки сена. Приготовленный набор предметов поджигается, и одна из участниц обряда спрашивает, а вторая, обходя корову против солнца, отвечает:

- Кодэс тшынан?

- Кекуре ки волидзес, урекиволидзес. Кытысь волін, бӧр сэтче мун, пиняд бӧжтэ курччи да тодьн лойси. ${ }^{50}$
- Кого окуриваешь?

- Уроки-сглаз окуриваю.

Откуда приходил, туда обратно возвращайся, зубами хвост прикуси и барахтайся в топи.

В двух последних ритуальных диалогах различаются заключительные фрразы - закрепки. В первом случае она усиливает совершаемое действие, а во втором - завершает лечебный ритуал, отсылая болезнь. 


\section{Причитание}

Несмотря на то, что в нашем распоряжении имеются только два образца подобных текстов ${ }^{51}$, можно рассмотреть их особенности. Традиция причитывания коми считается развитой, выделяются локальные традиции причети и жанровые разновидности. Так, в традиции ижемских коми выделяются не только похоронные и свадебные, но также колыбельные, календарные и трудовые причитания (Филиппова 2002).

(Мӧсльь бӧрдэл)

Тайтӧ, матиӧ, тайтӧ,

Сюрка,

Тайтӧ, тайтӧ, шӧӧ мада

Пукси шӧӧ, шӧӧ

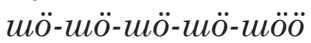

Гортӧ мадаэ, гортӧ,

Гортӧ, гортӧ, лматиӧ

Гортӧ, гортӧ, чӧскыд йӧлаэ

Гортэ, гортэ, ладаэ.

Гортэ локтэ, баксэ, тӧдэ кӧзяцика, и локтэ шыас мӧскьц. Мадаэ бара шыьас воис и бакестас, и кукйыс поллась.

Мӧс дзоньтэл:

Тайтэ, мадаэ,

Tайтэ, Сюрка

Тайтэ, мадаэ,

тайтэ, тайтээ,

Сӧӧ, мадаэ,

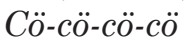

Чӧскьљ йӧлале сӧ.

Гортэ мадаэ,

Гортэ, гортэ ! ${ }^{52}$
(Плач корове)

Тайтӧ-иди, матушка

Сюрка (букв. Рогатая),

Иди милая,

Домой милая, домой, Домой, домой, матушка, Домой, домой, вкусномолочная, Домой, домой, милая, Домой идёт, мычит, знает хозяйку и идёт на голос. Милая придёт на голос и замычит, телёнок ей в ответ.

Ласка коровы:

Иди, коровушка, милая, Иди, коровушка, Рогатая, Иди, коровушка, милая, Иди, коровушка, иди.

Сӧо, милая

Cö-cö-cö-cö

Вкусномолочная, Домой, милая, Домой, домой! 
Зафиксированные причитания близки к колыбельным. Интересно заметить, что в первом случае текст именуется мӧсль бӧрдэл 'причитание корове', во втором - лӧс дзоньтэл с использованием отглагольного существительного, образованного от глагола дзоньтыны 'исправить, сделать целым', который в ижемском диалекте коми языка означает также 'приласкать'. Функция текста может рассматриваться как выражение ласки к животному, необходимое для поддержки его здорового состояние.

\section{Заключение}

На основе материалов по скотоводческой традиции коми, представленных в основном современными записями, можно выделить разные формы заговорно-заклинательных текстов. Исходя из формальных особенностей, мы разделили их на пять разновидностей. Но не стоит забывать, что тексты являются вербальным уровнем обряда, и для всестороннего анализа необходимо изучение семантики и структуры самого обряда, выявление взаимосвязей с акциональным и предметным кодом обрядов. Кроме того, нерассмотренными остались комментарии информантов, так называемый "речевой контекст», поэтика текстов, анализ которых необходим для изучения вербального уровня скотоводческих обрядов.

\section{Сокращения}

АФА - аудиофонд автора

НА Коми НЦ - Научный архив Коми Научного центра УрО РАН

НМ РК - Национальный музей Республики Коми

РФА - рукописный фонд автора

ФА СГУ - Фольклорный архив Сыктывкарского Государственного университета 
ФФ ИЯЛИ - Фольклорный фонд Института языка литературы и истории Коми Научного центра УрО РАН

ФФА - фотофонд автора

\section{Примечания}

1 Сопоставимо с понятием ас гӧгӧр тӧдны 'знать вокруг себя', челядь гӧгӧр тӧдны 'знать вокруг детей', обозначает сохранность целостности, в целом - здоровья, в чём выражается профилактическая основа заговорной традиции коми (Панюков 2009: 166-204).

2 Зап. Л. С. Лобанова в 1994 г. в с. Аныб Усть-Куломского р-на от Валентины Егоровны Лобановой, 1953 г. р. (АФА).

3 Нилкыь означает заговор, заклинание, заговорно-заклинательный акт (Уляшев 1999; Панюков 2009: 166-204).

4 Зап. Л. С. Лобанова 23.06.2006 г. в пос. Чекша Ношульского с/с Прилузского р-на от Александра Павловича Вахнина, 1928 г. p. (АФА).

5 Подробнее об отличии ритуальной практики и рассказе о ней см. Неклюдов 2011.

6 Материалы Павла Савваитова, относящиеся к середине XIX в., в Отделе рукописей Российской национальной библиотеки (г. СанктПетербург); материалы Василия П. Налимова начала XX в. в Архиве Финно-угорского общества (Suomalais-Ugrilainen Seuran Arkisto); фольклорно-этнографические материалы, собранные студентами Педтехникума в 1930-е гг., хранящиеся в Национальном музее Республики Коми (об этих материалах см. статьи Юлии Крашенинниковой и Светланы Низовцевой в данном сборнике); материалы фольклорноэтнографических и лингвистических экспедиций сотрудников Коми Научного центра 1960-1980-х гг.

7 Подобного типа материалы содержат указание на номер фотографии.

8 Зап. Г. С. Савельева \& А. В. Панюков в 1999 г. в с. Пучкома Удорского р-на от Марьи Васильевны Матвеевой, 1946 г. р. (ФФ ИЯЛИ: A0525-13).

9 Зап. Л. С. Лобанова 20.06.2005 в дер. Гарь Спаспорубского с/с Прилузского р-на от Клавдии Павловны Фоминой, 1937 г. р., уроженки д. Кулига (ФФ ИЯЛИ: А 1564). 
10 Зап. Л. С. Лобанова 23.06.2001 в с. Ёртом Удорского района от Галины Владимировны Матвеевой, 1961 г. р. (АФА).

11 Зап. Г. С. Савельева \& А. В. Панюков в 2000 г. в с. Нившера Корткеросского р-на от Анны Алексеевны Слюсер, 1906 г. р. (ФФ ИЯЛИ: B1114-73).

12 Зап. Т. Н. Канева в 1999 г. в п. Озъяг Кужбинского с/с Усть-Куломского р-на от А. И. Есевой, 1927 г. р. (ФФ ИЯЛИ: В1206).

13 Зап. Г. С. Савельева \& А. В. Панюков в 1999 г. в с. Пучкома Удорского р-на от Марьи Васильевны Матвеевой, 1946 г. р. (ФФ ИЯЛИ: B0510-69).

14 Зап. Л. С. Лобанова 23.06.2011 в с. Ёртом Удорского района от Нины Петровны Матвеевой, 1931 г. р. (АФА).

${ }^{15}$ Имеется в виду молитва «Да воскреснет Бог».

16 Зап. Г. С. Савельева \& А. В. Панюков в 2000 г. в с. Нившера Корткеросского р-на от Александры Матвеевны Жижевой, 1928 г. р. (ФФ ИЯЛИ: В1113-44).

${ }^{17}$ В качестве примера см. вышеприведённый текст.

18 Указанное значение частицы тай, встречающееся в ижемском диалекте, приводится в работе Галины Федюнёвой, где предлагается этимология этой частицы (Федюнёва 2009: 72).

19 Зап. Е.В. Ветошкина в 1978 г. в дер. Лыаты Кожмудорского с/с УстьВымский р-на от Козловой Ольги Ивановны, 1918 г.p. (НА Коми НЦ: Ф.5. Оп.2. Д.226-в. Л.48).

${ }^{20}$ Определения закрытая и открытая структуры принадлежат В. И. Харитоновой (см. Харитонова 1992).

${ }^{21}$ В коми языке шерсть и пух обозначаются одним словом.

22 Зап. Г. С. Савельева \& А. В. Панюков в 1999 г. в с. Пучкома Удорского р-на от Марьи Васильевны Матвеевой, 1946 г. р. [ФФ ИЯЛИ:А0525-14].

23 Зап. Л. С. Лобанова 23.06.2001 в с. Ёртом Удорского района от Галины Владимировны Матвеевой, 1961 г. р. (АФА).

24 Зап. Л. С. Лобанова 23.06.2011 в с. Ёртом Удорского района от Нины Петровны Матвеевой, 1931 г. р. (АФА).

25 Зап. Г. С. Савельева \& А. В. Панюков в 2000 г. в с. Нившера Корткеросского р-на от Александры Матвеевны Жижевой, 1928 г. р. (ФФ ИЯЛИ: В1113-46). 
26 Зап. Г. С. Савельева \& А. В. Панюков в 2000 г. в с. Нившера Корткеросского р-на от Александры Матвеевны Жижевой, 1928 г. р. (ФФИЯЛИ: В1113-47).

27 Зап. Л. Я. Кондратьева в 1935 г. в с. Ужга Койгородского р-на (НМ РК: КП-12485. Л. 514).

28 Зап. Тараканова в 1935 г. в с. Пажга Сыктывдинского р-на (НМ РК: КП-12485. Л. 497).

29 Зап. К. Редеи в 1964 г. на верхней Вычегде (Rédei1978: 234).

30 Зап. Г. С. Савельева \& А. В. Панюков в 1996 г. в с. Нившера Корткеросского р-на от Марьи Дмитриевны Михайловой, 1922 г. р.; Агнии Ивановны Жижевой, 1937 г. р. (ФФ ИЯЛИ: В1102-41).

31 Зап. Г. С. Савельева \& А. В. Панюков в 1996 г. в с. Нившера Корткеросского р-на от Нины Дмитриевны Михайловой,1923 г. р. (ФФ ИЯЛИ:В1102-19).

32 Ёма - персонаж фольклора и мифологии коми, в данном случае выступает маркером чужого пространства, противопоставленного своему дому, хозяйству.

33 Зап. Л. С. Лобанова 22.06.2005 в дер. Кулига Спаспорубского с/с Прилузского р-на от Марии Григорьевны Фоминой, 1928 г. р., уроженки дер. Шпал (АФА).

34 Зап. Л. С. Лобанова 20.06.2005 в дер. Гарь Спаспорубского с/с Прилузского р-на от Клавдии Павловны Фоминой, 1937 г. р., уроженки д. Кулига (ФФ ИЯЛИ:А1564).

35 Зап. Л. С. Лобанова в 1994 г. в с. Аныб Усть-Куломского р-на от Валентины Егоровны Лобановой, 1953 г. р. (АФА).

36 Зап. Л. С. Лобанова 28.06.2011 в с. Ёртом Удорского района от Нины Петровны Матвеевой, 1931 г. р. (АФА).

37 Зап. Л. С. Лобанова в 1994 г. в с. Аныб Усть-Куломского р-на от Анны Дмитриевны Пименовой, 1914 г. р. (АФА).

38 Зап. В. К. Арефьева в 2011 г. в с. Чупрово Удорского района от Н. М. Шлоповой, 1946 г. р. (РФА).

39 Зап. В. К. Арефьева в 2011 г. в дер. Муфтюга Чупровского с/с Удорского района от Нины Геннадьевны Фёдоровой, 1955 г. р. (РФА).

40 Добавлено другим почерком чёрной пастой.

${ }^{41}$ Добавлено над следующей строкой синей пастой другим почерком. 
${ }^{42}$ Фото сделано Л. С. Лобановой 28.06.2011 в с. Ёртом Удорского р-на с рукописной тетради Нины Петровны Матвеевой, 1931 г. р. (ФФА: 28_06-142).

43 Зап. Л. С. Лобанова 28.06.2011 в с. Ёртом Удорского района от Нины Петровны Матвеевой, 1931 г. р. (АФА).

44 Дер. Крестово входила в состав Ёртомского с/с. Это место примечательно тем, что имело статус религиозного центра, некогда здесь располагался монастырь, с территории которого в с. Ёртом была сплавлена первая церковь.

${ }^{45}$ Фото сделано Л. С. Лобановой 28.06.2011 в с. Ёртом Удорского р-на с рукописной тетради Нины Петровны Матвеевой, 1931 г. p. (ФФА: 28_06-79).

${ }^{46}$ Более подробно обряды Великого четверга рассмотрены в Лобанова 2012.

47 Дукарт Н. И. Полевые записи. - Научный архив отдела этнографии Института языка, литературы и истории. Приводится по Конаков 1993: 56.

48 Зап. в 2002 г. в д. Урнышевская Спаспорубского с/с Прилузского р-на от М. Д. Урнышевой, 1929 г. р. (ФА СГУ 03109-17). Приводится по Календарь коми 2002: 67.

49 Зап. А. Н. Рассыхаев \& Л. А. Сажина в 2002 г. в д. Карвуджем Гривенского с/с Койгородского р-на от Е. М. Ушаковой, 1918 г. р. (ФФ ИЯЛИ:А1604).

50 Зап. Л. С. Лобанова в 1994 г. в с. Аныб Усть-Куломского р-на от Анны Дмитриевны Пименовой, 1914 г. p. (АФА).

${ }^{51}$ Выражаю благодарность сотрудникам Фольклорного фонда ИЯЛИ Галине Савельевой и Анатолию Панюкову за указание на тексты и возможность ознакомления с ними.

52 Зап. А. К. Микушев \& П. И. Чисталёв в 1960 г. в с. Брыкаланск (дер. Котлас) Ижемского р-на от Ульяны Осиповны Сметаниной, 65 лет, и Анны Ивановны Сметаниной (ФФ ИЯЛИ К-45: 12). 


\section{Литература}

Ветошкина, Елена 1982. Производственные и семейно-бытовые заговоры у коми. - Национальное и интернациональное в коми литературе и больклоре (Труды Института языка, литературы и истории, вып. 26). Сыктывкар, 87-97.

Жилина, Татьяна 1975. Верхнесысольский диалект коли языка. Москва: Наука.

Календарь коми 2002 = Филиппова, Валентина \& Канева, Татьяна (сост.) \& Власов, Андрей (ред.). Традииионный народный календарь коли: Материальь. Сыктывкар.

Конаков, Николай 1993. От Святок до Сочельника: Коми традиционнье календарные обряды. Сыктывкар.

Кудряшова, Вера 1991. Заговоры народа коми - Рочев, Юрий (ред.). Общее и особенное в жанрах коми фбольклора и литературы (Труды Института языка, литературы и истории, вып. 48). Сыктывкар, $34-45$.

КЭСК = Лыткин, Василий \& Гуляев, Евгений 1999. Краткий этимологический словарь коли языка. Сыктывкар: Коми книжное издательство.

Лобанова, Людмила 2012. Скотоводческие ритуалы Великого четверга. - Фольклористика коли (Труды Института языка, литературы и истории, вып. 70). Сыктывкар: Коми НЦ УрО РАН, 101-121.

Неклюдов, Юрий 2011. «Этнографический факт» и его фольклорные экспликации. - Байбурин, Альберт \& Щепанская, Татьяна (ред.). Фольклор и этнографбия. К 90-летию со дня рождения К. В. Чистова. Санкт-Петербург: МАЭ РАН, 40-47.

Панюков, Анатолий 2009. Динамика развития коми фбольклорных традииий в контексте теории самоорганизации. Сыктывкар: Издательство Коми НЦ УрО РАН.

Пермяков, Григорий 1988. К вопросу о структуре паремиологического фонда. - Пермяков, Григорий. Основы структурной паремиологии. Москва: Наука. 
Попова, Элеонора 2000. Междометие. - Федюнёва, Галина (ред.). Ӧнія коми кыьв. Современный коми язык. Морфбология. Сыктывкар: Коми книжное издательство.

Сидоров, Алексей 1997. Знахарство, колдовство и порча у народа коли. Материалы по психологии колдовства. Санкт-Петербург.

ССКЗД 1961 = Жилина, Татьяна \& Сахарова, Марфа \& Сорвачёва, Валентина (сост.). Сравнительный словарь коли-зырянских диалектов. Сыктывкар.

Толстой, Никита 1984. Фрагмент славянского язычества: архаический ритуал-диалог. - Толстой, Никита (ред.). Славянский и балканский фольклор: Этногенетическая общность и типологические параллели. Москва: Наука, 5-72.

Толстой, Никита 1993. Ещё раз о славянском ритуальном диалоге. - Толстая, Светлана \& Цивьян, Татьяна (ред.). Славянское и балканское языкознание: Структура малых фбольклорных фборм. Москва: Наука, 82-110.

Уляшев, Олег 1999. Нимкыв [Заговор]. - Сиикала, Анна-Леэна \& Напольских, Владимир \& Хоппал, Михай (ред.). Энииклопедия уральских мифбологий. Т. 1. Мифбология коми. Москва: ДиК, $256-258$.

Федосова, Ксения 2007. Заговоры в обряде первого выгона скота: принципы варьирования и стратегии текстопорождения в устной и письленной традищии. Автореферат диссертации на соискание учёной степени кандидата филологических наук по специальности 1001 09. Москва.

Федюнёва, Галина 2009. К этимологии частицы тай 'ведь, же' в коми и мансийском языках. - Гуманитарные науки в Сибири, № 4. 70-72.

Филиппова, Валентина 2002. Причитание в контексте обрядовой поәзии. - Фольклористика Коми. Сыктывкар: Издательство Коми НЦ УрО РАН, 61-72.

Харитонова, Валентина 1992. Заговорно-заклинательная поэзия восточных славян. Конспекты лекиий. Львов.

Syrjänische Texte 2006. Gesammelt von Uotila, Toivo E. \& Kokkonen, Paula. Bd. 5. Helsinki.

Zyrian Folklore Texts 1978. Compiled by Rédei, Károly. Budapest: Akadémiai Kiadó. 


\section{ФОЛЬКЛОРИСТИКА КОМИ: исследования и материалы}

\section{http://www.folklore.ee/rl/pubte/ee/sator/sator17/}

ISSN 1736-0323

ISBN 978-9949-586-24-0

DOI: $10.7592 /$ Sator.2016.17

Тарту 2016

Авторы: Ирина Ильина, Юлия Крашенинникова, Павел Лимеров, Людмила Лобанова, Светлана Низовцева, Алексей Рассыхаев, Анатолий Панюков, Галина Савельева,

Олег Уляшев

Редактор серии: Маре Кыйва

Редакторы-составители выпуска: Людмила Лобанова \& Николай Кузнецов

Оформление обложки: Анатолий Панюков \& Андрес Куперьянов

Верстка \& HTML: Диана Кахре

Печатное издание: ФОЛЬКЛОРИСТИКА КОМИ: исследования и материалы. SATOR 17. Тарту 2016

Составление, техническое оформление и печать книги осуществлены при поддержке Эстонского институционального исследовательского гранта 22-5 (Религиозные и нарративные аспекты фольклора).

Оформление электронного издания осуществлено при поддержке проекта ЕККМ14-344 “Расширение областей применения и представление эстонского языка, культуры и фольклора в электронных информационных средствах".

(с) EKM Teaduskirjastus / Научное издательство ЭЛМ

(c) Авторы

(с) Анатолий Панюков \& Андрес Куперьянов 